\title{
Do physical therapy modalities have additional benefit over exercise therapy in the management of Ankylosing Spondylitis? A randomized controlled trial
}

\section{Ankilozan spondilit tedavisinde fizik tedavi yöntemlerinin egzersize ek olarak olumlu etkileri var mıdır? Randomize kontrollü çalışma}

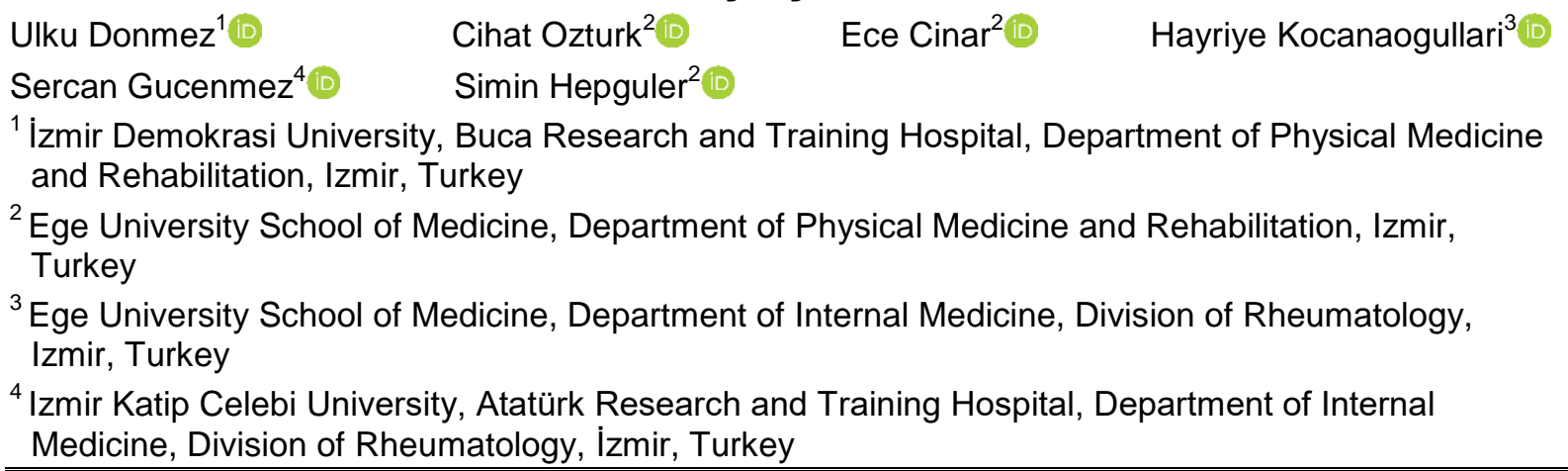

\section{ABSTRACT}

Aim: The aim of this study was to evaluate the effectiveness of microwave therapy and global postural reeducation (GPR) exercises on disease activity, pain, quality of life and functional status in patients with ankylosing spondylitis (AS).

Materials and Methods: 77 patients diagnosed with AS were included in the study. First group (n: 25) was treated with global postural reeducation exercises 5 days a week, for 3 weeks. Patients in the second group (n: 26), in addition to GPR, were treated with microwave therapy before each exercise session to warm lumbar paraspinal muscles. Third group (n: 26) consisted of controls. Subjects were evaluated at baseline, on the third week, third and six months.

Results: In the first group, improvement in all parameters was found to be significant $(p<0.05)$. Second group exhibited statistical improvement in all outcome measures $(p<0.05)$ except daytime pain $(p>0.05)$. In the control group, improvements in BASMI, BASDAI and Beck depression scores were statistically significant $(p<0.05)$. Intergroup comparisons showed a statistically significant difference among groups in all outcome measures at the sixth month follow-up $(p<0.05)$. First and second groups which received GPR demonstrated greater improvement in BASMI, BASFI, BASDAI and Beck depression inventory scores compared with the control group $(p<0.05)$.

Conclusion: Our results show that GPR has beneficial effects on disease activity, quality of life, pain and depression in patients with AS. We could not detect any additional benefits of microwave therapy applied before exercise.

Keywords: Ankylosing spondylitis, exercise, microwave, physical therapy.

\section{ÖZ}

Amaç: Bu çalışmanın amacı; AS hastalarında global postural reedukasyon (GPR) programı ve radar (mikrodalga) egzersizleri ve radar tedavisinin ağrı, hastalık aktivitesi ve fonksiyonel durum üzerine olan etkisinin araştırılmasıdır.

\footnotetext{
Corresponding author: Ece Cinar

İzmir Demokrasi University, Buca Research and Training

Hospital, Department of Physical Medicine and Rehabilitation, Izmir, Turkey

E-mail: ececinar1@gmail.com

Application date: 02.03.202

Accepted: 04.05.2021
} 
Gereç ve yöntem: 77 AS tanılı hasta çalışmaya dâhil edilmiştir. 1.gruba (n:25) 3 hafta boyunca haftada 5 gün, GPR egzersizleri verilmiştir. 2.gruptaki hastalara (n:26) aynı egzersiz programına ek olarak egzersiz öncesi lomber paraspinal kaslar üzerine 20 dakika radar tedavisi uygulandı. 3.grup ise kontrol grubu hastalardı. Tüm hastalar tedavi öncesi, tedavi sonrası 3.hafta, 3.ay ve 6.ayda değerlendirildi.

Bulgular: Grup içi değerlendirmede; egzersiz grubunda tedavi öncesine göre tedavi sonrası 6.ayda tüm değerlendirme parametrelerinde istatistiksel anlamlı iyileşme olduğu gözlendi $(p<0,05)$. Ikinci grupta ise tedavi öncesine göre tedavi sonrası 6.ayda gündüz ağrısı dışında tüm parametrelerde olumlu yönde gelişme olduğu saptandı $(p<0,05)$. Kontrol grubunda da tedavi öncesine göre tedavi sonrası 6.ayda BASMI, BASDAl ve Beck depresyon skorlarında anlamlı iyileşme saptandı $(p<0,05)$. Gruplar arası karşılaştırmada; tedavi sonrası 6.ayda tüm parametrelerde istatistiksel anlamlı fark saptandı $(p<0,05)$. Birinci ve ikinci gruplar yani egzersiz programı alan gruplarda, kontrol grubuna kıyasla BASMI, BASFI, BASDAl ve Beck depresyon envanterindeki iyileşme anlamlı olarak daha iyi saptanmıştır $(p<0,05)$.

Sonuç: AS hastalarında verilen GPR yönteminin hastalık aktivitesi, yaşam kalitesi, ağrı ve depresyon üzerine olumlu etkisi olduğu görüldü. Ancak bu çalışmada egzersiz öncesi ısıtıcı etkisinden yaralanılmak üzere verilen radar tedavisinin bu gelişmelere ek katkı sağlamadığı gözlendi.

Anahtar Sözcükler: Ankilozan spondilit, egzersiz, fizik tedavi, mikrodalga.

\section{INTRODUCTION}

Ankylosing spondylitis (AS) is a chronic, systemic inflammatory disease that affects the vertebral column, sacroiliac and peripheral joints and in some cases may be accompanied by extra articular symptoms (1). Spinal inflammation together with resulting pain and stiffness causes a progressive limitation of spinal movement and patients' functional activities. This in turn negatively affects quality of life and increases depressive symptoms. Hence early diagnosis and education of patients before spinal and peripheral joint deformities set in is of the utmost importance (2). Treatment strategies for AS include pharmacological agents as well as exercise and physical therapy modalities (3).

In recent years, there has been an increase in the number of research studies assessing the effectiveness of Global Postural Reeducation (GPR) in patients with chronic lower back pain and AS $(4,5)$. This program utilizes natural viscoelastic properties of tissues to help shortened muscles stretch and lengthen, stimulates antagonistic muscles to contract and therefore aims to correct postural asymmetry (4). GPR program mainly activates 4 distinct muscle groups (posterior static chain, anterior diaphragmatic chain, anterointernal pelvic chain and scapular triangle). Previous studies examining the effectiveness of GPR have mainly reported positive outcomes $(6,7)$.

Physical therapy modalities are employed in the treatment of AS in order to increase patients' exercise tolerance and to decrease inflammation and muscle spasm in and around affected joints (8). Evidence regarding the effectiveness of physical therapy agents is scarce. No previous studies were conducted to assess the influence of microwave therapy in the management of AS.

In this randomized controlled study, we aimed to evaluate the effects of microwave therapy in addition to GPR on pain, disease activity, spinal mobility, quality of life and depression in patients diagnosed as AS.

\section{MATERIAL and METHODS}

Patient selection: The study was conducted from February to October 2013. Patients who were diagnosed as AS according to Modified New York and/or ASAS criteria and who presented to our university hospital's Rheumatology and Physical Medicine and Rehabilitation outpatient clinics were assessed for inclusion in the study $(9,10)$. Only those subjects who were receiving appropriate medical treatment and who were independent in the activities of daily living were enrolled in the study.

Exclusion criteria were: exercising regularly during the previous 6 months, inability to walk independently, having a severe systemic illness that limited subject's participation in exercise, vertebral compression fracture, severe mental and/or emotional disorder, cardiac pacemaker or orthopedic implant and a history of spinal surgery. 
Study protocol was approved by the ethics board of our university hospital. Eighty-seven patients were screened for inclusion in the study. Ten patients were excluded and 77 were patients were included and randomized into 3 groups according to a computer generated number based randomization scheme. Patients in the first group ( $n: 25)$ received supervised group exercise sessions. Second group ( $\mathrm{n}: 26$ ), in addition to supervised hospital-based exercise sessions, received microwave therapy to paravertebral muscles. Patients who were randomized to the third group ( $\mathrm{n}: 26)$ were asked to continue routine daily physical activities.

Visits: Before enrollment, subjects were informed by a researcher about the study protocol and were asked to sign a written consent form. All subjects were assessed at baseline, 3rd week, 3rd month and 6th month visits by the same researcher.

Variables: After randomization, patients' sociodemographic characteristics, body mass index (BMI), symptom duration, time since diagnosis, comorbidities, and medical treatments were recorded. To assess spinal mobility, Bath Ankylosing Spondylitis Metrology Index (BASMI) was used (11). Bath Ankylosing Spondylitis Disease Activity Index (BASDAl) and Bath Ankylosing Spondylitis Functional Index (BASFI) were used to assess disease activity and functional limitations respectively $(12,13)$. Quality of life was evaluated using Ankylosing Spondylitis Quality of Life (ASQoL) questionnaire (14). Depression which is a known comorbidity in this patient population was assessed with Beck depression inventory (BDI) $(15,16)$. Patients were asked to mark their perceived pain levels on a 10 point visual analog scale (VAS), with higher scores representing more severe pain. Nighttime and daytime pain scores were questioned separately.

Procedures: Subjects in the first group were enrolled in a hospital-based GPR program for 3 weeks, 5 days a week. Each exercise group consisted of 5 or 6 subjects and each session lasted for 60 minutes. Main steps for every session were as follows:

1- Warm-up exercises (stretching exercises, 8 repetitions, 2 sets)

2- Lumbar vertebral range of motion exercises (8 repetitions, 2 sets)

3- Static and dynamic postural exercises ( 3-4 minutes for each posture)

4- Breathing exercises

5- Cooling down
Subjects in the second group received the same exercise program as the first group. Before each session, a technician administered microwave therapy with a frequency of $2450 \mathrm{MHz}$ to subjects' lumbar vertebral columns for 20 minutes using rectangular electrodes in order to heat paravertebral muscles (Enraf-Nonius, RADARMED 650+, Netherlands). After 3 weeks, all subjects were given pamphlets with printed photographic instructions showing home based GPR exercises. Subjects were telephoned every 4 weeks for 6 months in order to increase their adherence to the home exercise program.

The third group was comprised of controls who were instructed to continue their routine daily physical activities. No alterations were made to subjects' medical treatment protocols.

Statistical analysis: SPSS version 20.0 (IBM corp. 2011, USA) was used for all statistical analyses. Categorical data were analyzed using Chi-square test. Normal distribution of data was assessed using Shapiro-Wilk test. Data with and without a normal distribution were analyzed using parametric and non-parametric tests respectively. Intragroup analyses of repeated measurements were analyzed with Friedman's test while pairwise repeated measurements were compared with Wilcoxon signed ranks test. For each time point, intergroup comparisons among the three groups and pair-wise comparisons between groups were carried out using Kruskal-Wallis and Mann Whitney $U$ tests, respectively. $P$ values below 0.05 were considered to be statistically significant.

\section{RESULTS}

Data from 77 subjects were included in the final analysis. There were no drop-outs during the 6 month follow-up period. We did not observe any adverse events related to microwave or exercise therapy.

Subjects' baseline demographic characteristics, disease related and clinical parameters are presented in (Table-1).

Median age for the whole population was found to be 42.00 [21-68] years and there was no significant difference among the three groups $(p<0.05)$. Number of male subjects was higher than females in all three groups. $76.6 \%$ of subjects were married. Median BMI of the whole patient population was 26.88 [18.42-38.82] $\mathrm{kg} / \mathrm{m} 2$. These parameters did not differ significantly among the three study groups $(p<0.05)$. 
Table-1. Baseline demographic and disease characteristics.

\begin{tabular}{|c|c|c|c|c|c|}
\hline & $\begin{array}{l}\text { Exercise group } \\
\quad(n=25)\end{array}$ & $\begin{array}{c}\text { Exercise + } \\
\text { microwave } \\
\text { group }(n=26)\end{array}$ & $\begin{array}{l}\text { Control group } \\
\quad(n=26)\end{array}$ & $\begin{array}{l}\text { Total population } \\
\quad(n=77)\end{array}$ & $p$ \\
\hline \multicolumn{6}{|l|}{ Age (years) } \\
\hline $\begin{array}{l}\operatorname{med}[\min - \\
\max ]\end{array}$ & $43.0[21-64]$ & $39.5[22-59]$ & 42.50 [29-68] & $42.00[21-68]$ & 0.214 \\
\hline $\begin{array}{l}\mathrm{BMI}(\mathrm{kg} / \mathrm{m} 2) \\
\mathrm{med}[\mathrm{min}- \\
\mathrm{max}]\end{array}$ & $\begin{array}{l}27.10 \\
{[21.51-36.35]}\end{array}$ & $\begin{array}{l}25.92 \\
{[19.40-35.07]}\end{array}$ & $\begin{array}{l}26.96 \\
{[18.42-38.82]}\end{array}$ & $\begin{array}{l}26.88 \\
{[18.42-38.82]}\end{array}$ & 0.849 \\
\hline Sex & & & & & \\
\hline Male, n (\%) & $13(52.0)$ & $13(50.0)$ & $15(57.7)$ & $41(53.2)$ & 0.847 \\
\hline $\begin{array}{l}\text { Marital status, } \\
\mathrm{n}(\%)\end{array}$ & $20(80)$ & $17(65.4)$ & $22(84.6)$ & 59 (76.6) & 0.232 \\
\hline $\begin{array}{l}\text { Married } \\
\text { Single }\end{array}$ & $5(20)$ & 9 (34.6) & $4(15.4)$ & $18(23.4)$ & \\
\hline $\begin{array}{l}\text { Duration since } \\
\text { diagnosis, } \\
\text { years } \\
\text { (mean } \pm S D) \\
{[\text { min-max] }}\end{array}$ & $\begin{array}{l}8.64 \pm 6.47 \\
{[1-23]}\end{array}$ & $\begin{array}{l}5.32 \pm 6.12 \\
{[0.5-23]}\end{array}$ & $\begin{array}{l}10.88 \pm 7.16 \\
{[1-31]}\end{array}$ & $\begin{array}{l}8.27 \pm 6.91 \\
{[0.5-31]}\end{array}$ & $0.003^{\mathrm{a}, \mathrm{c}}$ \\
\hline $\begin{array}{l}\text { Symptom } \\
\text { duration, } \\
\text { years } \\
(\text { mean } \pm \text { SD) } \\
\text { [min-max] }\end{array}$ & $\begin{array}{l}13.76 \pm 8.73 \\
{[2-40]}\end{array}$ & $\begin{array}{l}9.76 \pm 6.49 \\
{[1-24]}\end{array}$ & $\begin{array}{l}14.57 \pm 6.69 \\
{[5-31]}\end{array}$ & $\begin{array}{l}12.68 \pm 7.56 \\
{[1-40]}\end{array}$ & $0.028^{\mathrm{a}}$ \\
\hline $\begin{array}{l}\text { Extent of } \\
\text { delay in } \\
\text { diagnosis, } \\
\text { years }\end{array}$ & $\begin{array}{l}5.12 \pm 6.55 \\
{[0-25]}\end{array}$ & $\begin{array}{l}4.44 \pm 3.79 \\
{[0-15]}\end{array}$ & $\begin{array}{l}3.69 \pm 4.46 \\
{[0-15]}\end{array}$ & $\begin{array}{l}4.41 \pm 5.01 \\
{[0-25]}\end{array}$ & 0.444 \\
\hline $\begin{array}{l}(\text { mean } \pm \text { SD }) \\
{[\text { min-max] }}\end{array}$ & & & & & \\
\hline Total BASMI & $3.40[1.6-8.6]$ & $2.90[0.8-7.8]$ & $4.30[2.2-8.4]$ & & $0.030^{\mathrm{a}}$ \\
\hline BASDAI & $3.16[0.72-7.58]$ & $3.66[0.28-7.06]$ & 2.52 [0.36-9.90] & & 0.450 \\
\hline BASFI & $3.17[0.38-6.48]$ & 2.59 [0.06-7.73] & $1.76[0.04-9.56]$ & & 0.742 \\
\hline BDI & $15.0[4-25.0]$ & $12.5[4-41.0]$ & $16.5[1-43.0]$ & & 0.910 \\
\hline ASQOL & $8.0[1-15.0]$ & $6.0[0-16.0]$ & $6.0[0-18.0]$ & & 0.918 \\
\hline Nighttime pain & $3.0[0-8.0]$ & $3.5[0-8.0]$ & $3.0[0-8.0]$ & & 0.448 \\
\hline Daytime pain & $2.0[0-7.0]$ & $1.0[0-10.0]$ & $2.0[0-10.0]$ & & 0.572 \\
\hline
\end{tabular}

BMI: Body mass index, BASFI: Bath Ankylosing Spondylitis Functional Index BASDAI: Bath Ankylosing Spondylitis Disease Activity Index, BASMI: Bath Ankylosing Spondylitis Metrology Index. med [min-max]: median [minimum-maximum]; SD: Standard deviation, $p: p$ value for comparison among all three groups. a: statistically significant difference between control group and exercise+ microwave group; b: statistically significant difference between control group and exercise group c: statistically significant difference between exercise group and exercise+ microwave group 
Table-2. Changes in clinical parameters through time and inter and intra-group comparisons.

\begin{tabular}{|c|c|c|c|c|c|}
\hline & & $\begin{array}{l}\text { Exercise group } \\
\qquad(n=25)\end{array}$ & $\begin{array}{c}\text { Exercise + } \\
\text { microwave group } \\
(n=26)\end{array}$ & Control group & $\mathbf{P}$ * \\
\hline \multirow{5}{*}{$\begin{array}{l}\text { Total BASMI } \\
\text { med [min-max] }\end{array}$} & Baseline & 3.4 [1.6-8.6] & $2.9[0.8-7.8]$ & $4.3 \quad[2.2-8.4]$ & $0.030^{\mathrm{a}}$ \\
\hline & 3rd week & $2.4[0.6-7.4]$ & $2.0[0.4-6.4]$ & 4.3 [2.2-8.2] & $0.000^{a, b}$ \\
\hline & 3rd month & $2.2[0.4-6.8]$ & $1.6[0.4-6.0]$ & 4.2 [2.2-8.2] & $0.000^{a, b}$ \\
\hline & 6th month & $2.0[0.4-6.4]$ & $1.4[0.4-6.4]$ & 4.2 [2.2-8.2] & $0.000^{a, b}$ \\
\hline & $p^{* *}$ & 0.000 & 0.000 & 0.000 & \\
\hline \multirow{5}{*}{$\begin{array}{l}\text { BASDAI } \\
\text { med [min-max] }\end{array}$} & Baseline & $3.16[0.72-7.58]$ & $3.66[0.28-7.06]$ & $2.52[0.36-9.90]$ & 0.450 \\
\hline & 3rd week & $1.86[0.4-4.22]$ & $1.81[0.18-6.82]$ & $2.20[0.56-9.86]$ & $0.000^{\mathrm{a}, \mathrm{b}}$ \\
\hline & 3rd month & $2.04[0.10-4.98]$ & $1.49[0.0-5.84]$ & $2.04[0.46-9.08]$ & $0.000^{a, b}$ \\
\hline & 6th month & $1.20[0.00-3.54]$ & $0.84[0.00-3.16]$ & $2.35[0.50-8.60]$ & $0.000^{\mathrm{a}}$ \\
\hline & $p^{* *}$ & 0.000 & 0.000 & 0.000 & \\
\hline \multirow{5}{*}{$\begin{array}{l}\text { BASFI } \\
\text { med [min-max] }\end{array}$} & Baseline & 3.17 [0.38-6.48] & $2.59[0.06-7.73]$ & $1.76[0.04-9.56]$ & 0.742 \\
\hline & 3rd week & $1.47[0.0-4.19]$ & $1.43[0.0-4.93]$ & $1.86[0.0-9.03]$ & $0.000^{a, b}$ \\
\hline & 3rd month & $1.37[0.0-4.44]$ & 0.94 [0.0-3.92] & 1.65 [0.0-8.73] & $0.000^{a, b}$ \\
\hline & 6th month & $0.87[0.0-4.42]$ & $0.74 \quad[0.0-3.99]$ & $1.98[0.0-8.85]$ & $0.000^{a, b}$ \\
\hline & $p^{* *}$ & 0.000 & 0.000 & 0.816 & \\
\hline \multirow{5}{*}{$\begin{array}{l}\text { BDI } \\
\text { med [min-max] }\end{array}$} & Baseline & $15.0[4-25.0]$ & 12.5 [4-41.0] & $16.5[1-43.0]$ & \\
\hline & 3rd week & $10.0[0-20.0]$ & 7.5 [0-31.0] & $16.0[0-42.0]$ & 0.910 \\
\hline & 3rd month & $7.0[0-15.0]$ & $5.0[0-25.0]$ & $14.0[0-43.0]$ & $0.000 a, b$ \\
\hline & 6th month & $5.0[0-15.0]$ & $4.0[0-30.0]$ & $15.5[0-41.0]$ & $0.000 a, b$ \\
\hline & $p^{* *}$ & 0.000 & 0.000 & 0.000 & $0.000 a, b$ \\
\hline \multirow{5}{*}{$\begin{array}{l}\text { ASQOL } \\
\text { med [min-max] }\end{array}$} & Baseline & $8.0 \quad[1-15.0]$ & $6.0 \quad[0-16.0]$ & $6.0[0-18.0]$ & 0.918 \\
\hline & 3rd week & $4.0[0-12.0]$ & $3.0[0-12.0]$ & $6.0[0-18.0]$ & $0.000 a, b$ \\
\hline & 3rd month & $3.0 \quad[0-10.0]$ & $2.0 \quad[0-11.0]$ & $5.0 \quad[0-18.0]$ & $0.000 a, b$ \\
\hline & 6th month & $3.0 \quad[0-8.0]$ & $1.0 \quad[0-16.0]$ & $6.0 \quad[0-18.0]$ & $0.000 a, b$ \\
\hline & $p^{* *}$ & 0.000 & 0.000 & 0.000 & \\
\hline \multirow[t]{5}{*}{ Nighttime pain } & Baseline & $3.0[0-8.0]$ & $3.5[0-8.0]$ & $3.0[0-8.0]$ & 0.448 \\
\hline & 3rd week & $3.0[0-5.0]$ & $2.0[0-6.0]$ & $3.0[0-8.0]$ & $0.000^{a, b}$ \\
\hline & 3rd month & $1.0[0-4.0]$ & $1.0[0-5.0]$ & $3.5[0-7.0]$ & $0.000^{a, b}$ \\
\hline & 6th month & $1.0[0-4.0]$ & $1.0[0-5.0]$ & $3.5[0-7.0]$ & $0.000^{a, b}$ \\
\hline & $p^{* *}$ & 0.000 & 0.000 & 0.768 & \\
\hline \multirow[t]{5}{*}{ Daytime pain } & Baseline & $2.0[0-7.0]$ & $1.0[0-10.0]$ & $2.0[0-10.0]$ & 0.572 \\
\hline & 3rd week & $2.0[0-5.0]$ & $1.0[0-6.0]$ & $2.0[0-10.0]$ & 0.130 \\
\hline & 3rd month & $1.0[0-5.0]$ & $1.0[0-5.0]$ & $1.5[0-10.0]$ & 0.201 \\
\hline & 6th month & $1.0[0-5.0]$ & $1.0[0-4.0]$ & 2.0 [0-9.0] & $0.043^{a, b}$ \\
\hline & $p^{* *}$ & 0.001 & 0.001 & 0.468 & \\
\hline
\end{tabular}

BASFI: Bath Ankylosing Spondylitis Functional Index BASDAI: Bath Ankylosing Spondylitis Disease Activity Index, BASMI: Bath Ankylosing Spondylitis Metrology Index; med [min-max]: median [minimum-maximum].

* $\mathrm{p}$ value for inter-group comparisons (Kruskal Wallis test); ${ }^{* *} \mathrm{p}$ value for intra-group comparisons (Friedmann test); a: statistically significant difference between control group and exercise+ microwave group; b: statistically significant difference between control group and exercise group c: statistically significant difference between exercise group and exercise+ microwave group. 
Median symptom duration for the whole patient population was $12.68 \pm 7.56[1-40]$ years. Symptom duration was found to be significantly shorter in the second group compared to the controls $(p=0.08)$. This difference was reflected in the three-way comparison of groups as well $(p=0.028)$.

Similarly, duration since diagnosis was found to be longer in the second group compared to the other groups $(p=0.003)$. Median duration of diagnosis for the whole population was $8.27 \pm 6.91$ [0.5-31] years. Extent of delay in diagnosis was $4.41 \pm 5.01$ [0-25] years for the entire cohort and did not differ among the three study groups $(p<0.05)$.

Median BASMI measurements in the control group (4.30 [2.2-8.4]) were significantly worse compared to the second group (2.90 [0.8-7.8]) $(p=0.011)$.

Baseline BASDAI, BASFI, BDI and VAS scores were found to be similar in all three groups $(p<0$, 05).

\section{Change in clinical parameters through time:}

Changes in studied parameters during the study period and inter-group comparisons are presented in (Table-2).

All three groups' BASMI scores showed significant improvement in time $(p<0,05)$. In all time points, changes were shown to be significantly better in both first and second groups compared to the control group, however no difference was observed between the two groups ( $p>0,05)$.

Changes in BASDAI and BAFI scores were statistically significant in all study groups $(p<0$, 05). Similar to BASMI scores, BASDAI and BASFI scores were shown to improve more significantly in those groups that received exercise treatment, with no difference between the first and second groups.

BDI and ASQoL scores also showed greater improvement in the first two groups compared with controls and this difference being statistically significant $(p<0.05)$. Nighttime pain VAS scores did not improve significantly over time in the control group while first and second groups showed significant improvement $(p<0.05)$. Daytime pain VAS scores were analyzed to be significantly better in the first and second groups at the $6^{\text {th }}$ month visit compared to the controls $(p<0.05)$.

\section{DISCUSSION}

Conventional exercise methods aiming to stretch paravertebral muscles, strengthen spinal extensor muscle groups and breathing exercises are recommended and play an important role in the care of patients with AS (17-21). Aerobic exercises have the additional benefit of improving pulmonary and cardiac functions (22-24). Early initiation of an appropriate and regular exercise regime has been shown to alleviate disease symptoms and improve physical functions in the early stages of AS (25).

Exercise treatment may be planned in a supervised or unsupervised form, individually or with a group, as well as in a hospital or home setting. Group exercises have been reported to improve stiffness, spinal mobility and functional capacity more effectively compared to home exercises in patients with AS $(19,26-28)$. Hidding et al. (19) and Helliwel et al. (26) proposed that group exercises are more effective than home exercises in alleviating social isolation and increasing spinal mobility. Sweeney et al. (29) suggested that lack of significant improvement in BASDAI scores in home exercise groups might be due to poor exercise compliance. Nevertheless, a meta-analysis showed that home exercise programs were still more beneficial than no exercise at all, in regard to both disease activity and quality of life (30).

In daily practice, physical therapy modalities are used in order to increase exercise tolerance, decrease inflammation, muscle spasms and pain. Most commonly employed methods are massage therapy, hydrotherapy, superficial and deep heating modalities and analgesic electrical currents (8). However evidence regarding the efficacy and superiority of these modalities is lacking (17). To date, no study was carried out to test the efficacy of microwave therapy, which is a diathermy agent.

In the current study, we observed that GPR, which is an alternative to conventional exercise protocols, was effective in improving spinal mobility, disease activity, functional status, quality of life and depression but we could not detect an additional benefit of pre-exercise microwave application.

There is no consensus regarding the optimum frequency, duration and type of exercise in the treatment of AS (28). Our subjects were enrolled in a hospital-based, supervised group exercise 
program for 3 weeks, 5 days a week, after which they were instructed to continue exercising at home.

GPR was first described in 1980 and is a method employed in the treatment of many musculoskeletal disorders. It has been reported in numerous studies to be superior to conventional exercises in the treatment of AS (7, 31-35). De las Penas et al. (7) who first studied the effectiveness of GPR in AS reported that subjects who attended weekly sessions for 15 weeks had better outcomes in BASMI, BASDAI, BASFI scores compared to controls. This positive effect of GPR was interpreted to result from the reintegration of shortened muscle chains. Durmuş et al. (33) reported that GPR group compared to conventional exercise group, displayed better improvement in pulmonary functions. They inferred that eccentric strengthening of spinal erector muscles was responsible for the decrease in thoracic kyphosis and the resulting improvement in pulmonary functions. Silva et al. (31) reported better improvement in BASMI scores in GPR group compared to conventional exercise group after 4 months. Patients in our current study population had relatively milder spinal limitations with mean BASMI scores being less than 4. Patients in both GPR groups showed significant improvements compared to the control group.

We have detected significant improvement in BASDAl scores in both GPR and GPR+ microwave groups. In a previous study performed by Pavy et al. (36) minimal clinically important difference (MCID) for BASDAI was reported to be $10 \mathrm{~mm}$ or $22.5 \%$. We have observed a median improvement of $20 \mathrm{~mm}$ in BASDAl scores with GPR treatment, which can be interpreted as clinically significant. Pavy et al. also reported MCID level for BASFI score as $7 \mathrm{~mm}$ or $17.5 \%$. In our current study, BASFI values for GPR group improved $18 \mathrm{~mm}$ which reflects significant clinical improvement.

Depression incidence in AS patients was shown to be higher than the general population. This has been explained by the negative effects of pain and functional limitations on the patients' mood and quality of life. Bodur et al. (37) stressed the positive influence of regular exercise on ASQoL scores. Aytekin et al. (38) reported better ASQoL scores in those patients who exercised at least 5 days a week compared to those that exercised 2-3 days per week. On a related note, Yigit et al. (39) reported better outcomes in BDI scores in subjects who exercised more than 3 times per week. In the current study, we observed more significant improvement in both BDI and ASQoL scores in the exercise groups compared to the control group.

Nonspecific chronic low back pain with an insidious onset is the most common symptom of AS. Chronic pain contributes to limitation of spinal mobility, functional status and negatively impacts quality of life. Gyurcsik et al. (34) found no positive effect of GPR treatment on pain scores in patients with AS. They stated that this might be a result of the small number of subjects enrolled in the study. Salaffi et al. (40) conducted a study on 825 AS patients and reported the MCID value for pain VAS score to be 1 unit or $25 \%$. In the current study, only those subjects in the first and second groups showed clinically significant improvement in nighttime VAS scores. Daytime pain VAS scores did not improve significantly in the first 3 months in any of the study populations. First two groups had significantly lower daytime pain VAS scores at the end of 6th month. This initial lack of significant improvement may be explained by subjects' already very mild baseline daytime pain VAS scores which may have made it difficult to assess the effect of our intervention on pain levels.

Although there is a scarcity of evidence regarding the effectiveness of physical therapy modalities in the treatment of AS, expert opinion supports the use of these agents. Primary aim of using physical therapy agents is to increase exercise tolerance. Balneotherapy and spa therapy were reported to impart beneficial effects when added to exercise protocols $(18,41-43)$. Enginar et al. (44) noted that a 15 session physical therapy program resulted in additional improvement in BASDAI, BASFI and BASMI scores when administered together with a home-based exercise program. Sari et al. (45) conducted a study in which they administered ultrasound and infrared therapies to lumbar regions of $30 \mathrm{AS}$ patients, who also received a home exercise program and observed a positive effect on pain, quality of life and depression scores. In the current study, we observed no additional benefit of microwave therapy over exercise in any of the measured parameters.

This is the first study to assess the possible effects of microwave therapy in AS patients. 
Presence of an exercise group that did not receive microwave therapy and zero dropout rate during the 6 month study period may be counted as our study's strengths. Most prominent limitations of the current study include not discriminating patients with axial and peripheral joint involvement, heterogeneity of medical treatments and relative smallness of our study population.

\section{CONCLUSION}

GPR exercises in addition to appropriate medical treatment and performed in a supervised hospital setting may have beneficial effects on disease activity, functional status, pain, quality of life and depression in patients with AS. However we did not detect any additional positive effects of microwave therapy over exercise. This may be in part due to the presence of relatively better baseline BASDAI, BASMI and VAS scores in the exercise+ microwave group. In order to assess the effectiveness of microwave therapy in AS patients, there is still need for broader studies that include larger numbers of subjects with moderate-severe disease activity.

Conflict of interest: Authors declare no conflict of interest

\section{References}

1. Khan MA. Ankylosing spondylitis: clinical features. In: Hochberg M, Silman A, Smolen J, Weinblatt M, Weisman M, eds. Rheumatology. 3rd ed. London, UK: Mosby: A Division of Harcourt Health Sciences Ltd; 2003:1161-81.

2. Sieper J, Rudwaleit M, Baraliakos X, Brandt J, Braun J, Burgos-Vargas R, et al. The Assessment of SpondyloArthritis international Society (ASAS) handbook: a guide to assess spondyloarthritis. Ann Rheum Dis suppl 2009; 68 Suppl 2: 1-44.

3. Ozgocmen S, Akgul O, Altay Z, Altindag O, Baysal O, Calis M, et al. Expert opinion and key recommendations for the physical therapy and rehabilitation of patients with ankylosing spondylitis. Int $\mathrm{J}$ Rheum Dis 2012; 15: 229-38.

4. Souchard PE, Meli O, Sgamma D, Pillastrini P. Rieducazione posturale globale. EMC - Medicina Riabilitativa 2009; 16: 1-10.

5. Bonetti F, Curti S, Mattioli S, Mugnai R, Vanti C, Violante FS, et al. Effectiveness of a 'Global Postural Reeducation' program for persistent low back pain: a non-randomized controlled trial. BMC Musculoskelet Disord 2010; 11: 285.

6. Amorim CS, Gracitelli ME, Marques AP, Alves VL. Effectiveness of global postural reeducation compared to segmental exercises on function, pain, and quality of life of patients with scapular dyskinesis associated with neck pain: a preliminary clinical trial. J Manipulative Physiol Ther 2014; 37: 441-7.

7. Fernandez-de-Las-Penas C, Alonso-Blanco C, Morales-Cabezas M, Miangolarra-Page JC. Two exercise interventions for the management of patients with ankylosing spondylitis: a randomized controlled trial. Am $J$ Phys Med Rehabil 2005; 84: 407-19.

8. Sozay S. Seronegatif Spondiloartropatili Hastalara Fiziksel Tip ve Rehabilitasyon Yaklaşımlari. Turkiye Klinikleri J Immunol Rheumatol 2004; 4: 72-6.

9. van der Linden S, Valkenburg HA, Cats A. Evaluation of diagnostic criteria for ankylosing spondylitis. A proposal for modification of the New York criteria. Arthritis Rheum 1984; 27: 361-8.

10. Rudwaleit M, van der Heijde D, Landewe R, Akkoc N, Brandt J, Chou CT, et al. The Assessment of SpondyloArthritis International Society classification criteria for peripheral spondyloarthritis and for spondyloarthritis in general. Ann Rheum Dis 2011; 70: 25-31.

11. Jenkinson TR, Mallorie PA, Whitelock HC, Kennedy LG, Garrett SL, Calin A. Defining spinal mobility in ankylosing spondylitis (AS). The Bath AS Metrology Index. J Rheumatol 1994; 21: 1694-8.

12. Akkoc Y, Karatepe AG, Akar S, Kirazli Y, Akkoc N. A Turkish version of the Bath Ankylosing Spondylitis Disease Activity Index: reliability and validity. Rheumatol Int 2005; 25: 280-4.

13. Calin A, Garrett S, Whitelock H, Kennedy LG, O'Hea J, Mallorie P, et al. A new approach to defining functional ability in ankylosing spondylitis: the development of the Bath Ankylosing Spondylitis Functional Index. J Rheumatol 1994; 21: 2281-5. 
14. Duruoz MT, Doward L, Turan Y, Cerrahoglu L, Yurtkuran M, Calis M, et al. Translation and validation of the Turkish version of the Ankylosing Spondylitis Quality of Life (ASQOL) questionnaire. Rheumatol Int 2013; 33: 2717-22.

15. Calin A, Marder A, Becks E, Burns T. Genetic differences between B27 positive patients with ankylosing spondylitis and B27 positive healthy controls. Arthritis Rheum 1983; 26: 1460-4.

16. Beck AT, Ward CH, Mendelson M, Mock J, Erbaugh J. An inventory for measuring depression. Arch Gen Psychiatry 1961; 4: 561-71.

17. Dagfinrud H, Kvien TK, Hagen KB. Physiotherapy interventions for ankylosing spondylitis. Cochrane Database Syst Rev 2008; CD002822.

18. van Tubergen A, Landewe R, van der Heijde D, Hidding A, Wolter N, Asscher M et al. Combined spa-exercise therapy is effective in patients with ankylosing spondylitis: a randomized controlled trial. Arthritis Rheum 2001; 45: 430-8.

19. Hidding A, van der Linden S, Boers M, Gielen X, de Witte L, Kester A, et al. Is group physical therapy superior to individualized therapy in ankylosing spondylitis? A randomized controlled trial. Arthritis Care Res 1993; 6: 117-25.

20. Viitanen JV, Lehtinen K, Suni J, Kautiainen H. Fifteen months' follow-up of intensive inpatient physiotherapy and exercise in ankylosing spondylitis. Clin Rheumatol 1995; 14: 413-9.

21. Kraag G, Stokes B, Groh J, Helewa A, Goldsmith $\mathrm{CH}$. The effects of comprehensive home physiotherapy and supervision on patients with ankylosing spondylitis-an 8-month followup. J Rheumatol 1994; 21: 261-3.

22. Zochling J, van der Heijde D, Dougados M, Braun J. Current evidence for the management of ankylosing spondylitis: a systematic literature review for the ASAS/EULAR management recommendations in ankylosing spondylitis. Ann Rheum Dis 2006; 65: 423-32.

23. Moldover JR, Bartels MN, Braddom RL. Cardiac Rehabilitation. Physical medicine and rehabilitation. Philadelphia: W.B. Saunders Company. 2000:665-86.

24. Jennings F, Oliveira HA, de Souza MC, Cruz Vda G, Natour J. Effects of Aerobic Training in Patients with Ankylosing Spondylitis. J Rheumatol 2015; 42: 2347-53.

25. Rosu OM, Ancuta C. McKenzie training in patients with early stages of ankylosing spondylitis: results of a 24week controlled study. Eur J Phys Rehabil Med 2014; 51: 261-8.

26. Helliwell PS, Abbott CA, Chamberlain MA. A Randomised Trial of Three Different Physiotherapy Regimes in Ankylosing Spondylitis. Physiotherapy 1996; 82: 85-90.

27. Analay $Y$, Ozcan E, Karan A, Diracoglu D, Aydin R. The effectiveness of intensive group exercise on patients with ankylosing spondylitis. Clin Rehabil 2003; 17: 631-6.

28. Santos H, Brophy S, Calin A. Exercise in ankylosing spondylitis: how much is optimum? J Rheumatol 1998; 25: 2156-60.

29. Sweeney S, Taylor G, Calin A. The effect of a home based exercise intervention package on outcome in ankylosing spondylitis: a randomized controlled trial. J Rheumatol 2002; 29: 763-6.

30. Liang $\mathrm{H}$, Zhang $\mathrm{H}$, Ji H, Wang $\mathrm{C}$. Effects of home-based exercise intervention on health-related quality of life for patients with ankylosing spondylitis: a meta-analysis. Clin Rheumatol 2015; 34: 1737-44.

31. Silva EM, Andrade SC, Vilar MJ. Evaluation of the effects of Global Postural Reeducation in patients with ankylosing spondylitis. Rheumatol Int 2012; 32: 2155-63.

32. Vanti C, Generali A, Ferrari S, Nava T, Tosarelli D, Pillastrini P. General postural rehabilitation in musculoskeletal diseases: scientific evidence and clinical indications. Reumatismo 2007; 59:192-201.

33. Durmus D, Alayli G, Uzun O, Tander B, Canturk F, Bek Y, et al. Effects of two exercise interventions on pulmonary functions in the patients with ankylosing spondylitis. Joint Bone Spine 2009; 76: 150-5.

34. Gyurcsik ZN, Andras A, Bodnar N, Szekanecz Z, Szanto S. Improvement in pain intensity, spine stiffness, and mobility during a controlled individualized physiotherapy program in ankylosing spondylitis. Rheumatol Int 2012; 32: 3931-6. 
35. Fernández-de-las-Peñas C, Alonso-Blanco C, Alguacil-Diego IM, Miangolarra-Page JC. One-Year Follow-up of Two Exercise Interventions for the Management of Patients with Ankylosing Spondylitis: A Randomized Controlled Trial. Am J Phys Med Rehab 2006; 85: 559-67.

36. Pavy S, Brophy S, Calin A. Establishment of the minimum clinically important difference for the bath ankylosing spondylitis indices: a prospective study. J Rheumatol 2005; 32: 80-5.

37. Bodur H, Ataman S, Rezvani A, Bugdayci DS, Cevik R, Birtane M, et al. Quality of life and related variables in patients with ankylosing spondylitis. Qual Life Res 2011; 20: 543-9.

38. Aytekin E, Caglar NS, Ozgonenel L, Tutun S, Demiryontar DY, Demir SE. Home-based exercise therapy in patients with ankylosing spondylitis: effects on pain, mobility, disease activity, quality of life, and respiratory functions. Clin Rheumatol 2012; 31: 91-7.

39. Yigit S, Sahin Z, Demir SE, Aytac DH. Home-based exercise therapy in ankylosing spondylitis: short-term prospective study in patients receiving tumor necrosis factor alpha inhibitors. Rheumatol Int 2013; 33: 71-7.

40. Salaffi F, Stancati A, Silvestri CA, Ciapetti A, Grassi W. Minimal clinically important changes in chronic musculoskeletal pain intensity measured on a numerical rating scale. Eur J Pain 2004; 8: 283-91.

41. Ciprian L, Lo Nigro A, Rizzo M, Gava A, Ramonda R, Punzi L, et al. The effects of combined spa therapy and rehabilitation on patients with ankylosing spondylitis being treated with TNF inhibitors. Rheumatol Int 2013; 33: 241-5.

42. Altan L, Bingol U, Aslan M, Yurtkuran M. The effect of balneotherapy on patients with ankylosing spondylitis. Scand J Rheumatol 2006; 35: 283-9.

43. Tishler M, Brostovski Y, Yaron M. Effect of spa therapy in Tiberias on patients with ankylosing spondylitis. Clin Rheumatol 1995; 14: 21-5.

44. ENGINAR, AU; UĞURLU, H. Effectiveness of Physical Therapy In Ankylosing Spondylitis: A Randomized Controlled Study. Mustafa Kemal Üniversitesi Tıp Dergisi, 2021 11.42: 44-50.

45. Sari H, Cakmak B, Can G. Efficacy of Physical Therapy Agents on Quality of Life and Emotional Status in Ankylosing Spondylitis. Turk J Phys Med Rehab 2003; 49: 8-12. 